\title{
In vitro antibacterial activities of crude extracts of nine plants on multidrug resistance bacterial isolates of wound infections
}

\author{
MUHAMMAD EVY PRASTIYANTO`, NI MADE BUNGA ANGGELIA DEWI, TUSY DIAH PRATININGTIAS, \\ NI MADE RAI PRATIWI, ANGGIS WINDAYANI, EKA WAHYUNENGSIH, ASTUTI, ELVIRA AMIR, \\ FANDHI ADI WARDOYO
}

Department of Medical Labolatory Technology, Faculty of Nursing and Health Sciences, Universitas Muhammadiyah Semarang. Jl. Kedungmundu Raya No. 18, Tembalang, Semarang 50273, Central Java, Indonesia. Tel.: +62-24-74760296, Fax.: +62-24-76740291, ”email: evy_prastiyanto@unimus.ac.id

Manuscript received: 29 April 2021. Revision accepted: 11 June 2021.

\begin{abstract}
Prastiyanto ME, Dewi NMBA, Pratiningtias TD, Pratiwi NMR, Windayani A, Wahyunengsih E, Astuti, Amir E, Wardoyo FA. 2021. In vitro antibacterial activities of crude extracts of nine plants on multidrug resistance bacterial isolates of wound infections. Biodiversitas 22: 2641-2647. Wound infections caused by bacteria is a become serious health problems, multidrug resistance bacteria (MDR) have increased this problem more severely, and therefore, antibacterial agents from natural biological sources are necessary to overcome these problems. This study examined the antibacterial activities of nine plants, i.e. garlic (Allium sativum), Solo garlic (Allium sativum), Java plum leaf (Syzygium cumini), Java plum fruit (Syzygium cumini), lime (Citrus aurantifolia), Kaffir lime (Citrus hystrix), Siamese weed (Chromolaena odorata), mangosteen (Garcinia mangostana) and bitter melon (Momordica charantia), against MDR bacteria isolated from wounds. The antibacterial activities were evaluated using agar well diffusion assay to determine the inhibition zones, and microdilution method to determine the value of minimum inhibitory concentration (MIC) and minimum bactericidal concentration (MBC). The best antibacterial activities were calculated as the most extensive inhibition zones with the smallest MIC and MBC values. Ethanol extracts from five plants (garlic, Solo garlic, Java plum (leaf), Kaffir lime and bitter melon) showed antibacterial activities against three MDR bacteria isolated from wounds. The bitter melon extract had the largest zones, $19.3 \mathrm{~mm}$ (methicillinresistant Staphylococcus aureus [MRSA]), $10.6 \mathrm{~mm}$ (ESßL-producing Escherichia coli), and $13 \mathrm{~mm}$ (carbapenemase-resistant Pseudomonas aeruginosa [CRPA]) with the smallest MIC and MBC values against MRSA (3.12 and $25 \mathrm{mg} / \mathrm{mL}), \mathrm{ES} \beta \mathrm{L}-\mathrm{producing} E$. coli $(12.25$ and $50 \mathrm{mg} / \mathrm{mL})$, and CRPA $(6.25$ and $25 \mathrm{mg} / \mathrm{mL})$. This concludes that bitter melon has the potential to be developed as an antibacterial agent, particularly against MRSA strains, ES $\beta$ L-producing E. coli, and CRPA that cause wound infections. Further in vivo research and the discovery of modes of action are needed to explain the antibacterial effects.
\end{abstract}

Keywords: CRPA, ES $\beta$ L-producing Escherichia coli, In vitro antibacterial activities, MRSA, wound infection

\section{INTRODUCTION}

Skin is an important organ that protects the body from damage and invasion of pathogenic bacteria (Xu et al. 2015). When the skin is damaged, the wound that exposes became prone to bacterial infection easily, which ultimately affects health. The wound may be healed in a few days or will develop for a long time and become chronic. A chronic wound is one of the most serious and fatal human problems (Han and Ceilleey 2017).

An infected wound may take longer time to recover, even may cause death in some cases (Liang et al. 2019). Staphylococcus aureus, Escherichia coli, and Pseudomonas aeruginosa are the bacteria commonly found in wounds (Pallavali et al. 2019). Antibiotics are commonly used to treat bacterial infections. However, the uncontrolled use of antibiotics contributes to the emergence of multidrug resistance (MDR) against many bacterial strains (Bologa et al. 2013). Patients infected with MDR bacteria may suffer from a prolonged disease that is difficult to treat and requires higher costs of treatment.

The Infectious Disease Society of America has considered the advent of several MDR bacteria, including those that are methicillin-resistant, extended-spectrum $\beta$ - lactamase (ES $\beta \mathrm{L})$-producing-resistant, and carbapenemase-resistant, as a distinct challenge in management (Boucher et al. 2009). The burn wound infections caused by methicillin-resistant Staphylococcus aureus (MRSA) (Chopra et al. 2016), MDR-P. aeruginosa (Nasser et al. 2020) and E. coli (Nasser et al. 2020) increase mortality and morbidity. The prevalence of infections caused by MRSA, MDR-P. aeruginosa and $E$. coli have increased in recent years.

Thus, new antibacterial agents from natural biological sources are required. Biological antibacterial agents can be obtained from honey (Panjaitan et al. 2018), mushrooms (Prastiyanto et al. 2020b; 2016), isolate bacteria from marine organisms (Asagabaldan et al. 2019), bacteriocins (Lestari et al. 2019), fruits (Prastiyanto et al. 2020d; Wahyuni et al. 2019), latex (Prastiyanto et al. 2020c) and seeds (Ilvani et al. 2019; Prastiyanto et al. 2020a). Many studies in the medical field reported the importance of traditional medicinal plants as alternatives of antimicrobial agents (Akhtar and Mirza 2015; Aumeeruddy-elalfi et al. 2015; Prastiyanto et al. 2021).

This study aimed to investigate the antibacterial potentials of traditional plants. Nine plants examined to study their antibacterial activities against resistant bacteria 
isolated from wounds, such as methicillin-resistant $S$. aureus (MRSA), (ES $\beta \mathrm{L})$-producing E. coli, and carbapenemase-resistant $P$. aeruginosa (CRPA). The nine plants were garlic, Solo garlic, Java plum (leaf), Java plum (fruit), lime, Kaffir lime, Siam weed, mangosteen, and bitter melon.

\section{MATERIALS AND METHODS}

\section{Plant materials and preparations of extracts}

Sampling of nine healthy plants were carried out in the rainy season of December 2019. Different parts of the plants were washed with water to remove unnecessary materials, dried in the sun for seven days, ground and then stored in sterile airtight containers for further usages in the next processes. Plant extracts were prepared by maceration with $96 \%$ ethanol solvent. $200 \mathrm{~g}$ of ground plant parts were soaked in $600 \mathrm{~mL}$ of solvent for 24 hours at room temperature, protected from light and were later shaken. The solvent replacement was done every day until the solution was clear, in which no more active compounds were contained in the dry powder. The supernatant was filtered using Whatman No.1 filter paper. The maceration solutions were concentrated under reduced pressure using a rotary evaporator at $50{ }^{\circ} \mathrm{C}$. The crude extracts were collected and allowed to dry at room temperature.

\section{Isolation, identification of bacterial strains and antibiotic sensitivity test}

MDR bacteria were directly isolated from wound samples obtained from patients in Dr. Kariadi Hospital, Semarang, Central Java, Indonesia. All isolates were identified by biochemical tests using Vitek®MS (bioM'erieux, Marcy l'Etoile, France), following minimum inhibitory concentration (MIC) interpretive standards from the Clinical Laboratory Standard Institute M100-S25 (CLSI 2019).

\section{Antibacterial assay of plant extracts \\ Agar well diffusion assay}

The antibacterial activities of various plant extracts were evaluated using a well-diffusion assay (Andleeb et al. 2020). MDR bacteria in a subculture on blood agar plate (BAP) media were incubated for 24 hours at $35 \pm 2^{\circ} \mathrm{C}$. The MDR bacterial colonies were dissolved in a normal saline solution with a turbidity equivalent to the $0.5 \mathrm{McF}$ arland standard. $100 \mu \mathrm{L}$ of each MDR bacterium was inoculated in Muller Hilton agar (MHA) by spreading the bacterium on the surface of the agar using a sterilized glass spreader. After five minutes of inoculation, the wells were prepared using a sterilized steel cork borer ( $1 \mathrm{~cm}$ in diameter). Four wells were made on each plate and loaded with each plant extract $(250,500,750$, and $1000 \mathrm{mg} / \mathrm{mL})$. All plates were then incubated aerobically at $35 \pm 2{ }^{\circ} \mathrm{C}$ for $16-20$ hours. Dimethyl sulfoxide (DMSO) was used as a negative control. Vancomycin and oxacillin were applied as positive controls for MRSA, ampicillin and meropenem for ESBLproducing bacteria, and meropenem and tetracycline were for CR bacteria. Antibacterial activities of the extracts were determined by measuring the diameters of the inhibition zones in mm against the tested organism.

\section{Determination of MIC and minimum bactericidal concentration $(M B C)$ of the plant extracts}

MIC values of plant extracts were determined in 12well sterile microplates using the broth microdilution method (CLSI 2018). Each test was carried out in triplicate. MHB $(100 \mu \mathrm{L})$ was placed into the well and plant extract $(100 \mu \mathrm{L})$ was put in the dilution series. $10 \mu \mathrm{L}$ bacterial cell suspensions were placed in each well. Microplates were incubated aerobically at $35 \pm 2{ }^{\circ} \mathrm{C}$ for $16-20$ hours. Oxacillin was used as positive controls for MRSA, ampicillin was applied for ESBL-producing bacteria, while meropenem was utilized for CR bacteria.

MIC was determined by selecting the lowest concentration of plant extracts that inhibited bacterial growth and was detected by the naked eye without any assistance from a particular device. Then, wells were subcultured using a $10 \mu \mathrm{L}$ inoculating loop on to a $5 \%$ sheep BAP at $(35 \pm 2)^{\circ} \mathrm{C}$ for $16-20$ hours of incubation. The lowest concentration of the extract that did not show any growth was defined as MBC (Yin et al. 2018).

\section{RESULTS AND DISCUSSION}

\section{Extract yield}

Ethanol extracts from nine plants were estimated to determine the extract yields (Table 1). Bitter melon showed the highest results, showing that its constituents were relatively polar.

\section{Tested microorganisms}

The results of the identification and test of bacterial sensitivity to antibiotics are presented in Figure 1. The results reveal that the bacteria isolated from the wounds were Staphylococcus aureus, Escherichia coli, and Pseudomonas aeruginosa, and they were resistant to several antibiotics. S. aureus was found resistant to oxacillin, gentamicin, ciprofloxacin, levofloxacin, moxifloxacin, erythromycin, clindamycin, tetracycline, and rifampicin. E. coli showed resistance against ampicillin, ampicillin-sulbactam, piperacillin-tazobactam, cefazolin, ceftazidime, ceftriaxone, cefepime, aztreonam, amikacin, gentamicin, and ciprofloxacin. Whereas, P. aeruginosa was observed resistant to ampicillin, ampicillin-sulbactam, piperacillin-tazobactam, cefazolin, ceftazidime, cefepime, aztreonam, amikacin, gentamicin, ciprofloxacin, meropenem and tigecycline. The bacteria isolated from the wound samples were methicillin-resistant St. aureus MRSA, (ES $\beta$ L)-producing E. coli and carbapenemaseresistant $P$. aeruginosa (CRPA). 


\section{The antibacterial activities}

Agar well diffusion assay

The antibacterial activities of the nine extracts were tested in vitro by agar well diffusion assay against three resistant bacteria causing wound infections. The antibacterial activities were determined by measuring the diameters of the inhibition zones in $\mathrm{mm}$ concerning MRSA, ES $\beta$ L-producing E. coli, and CRPA (Figure 2).

Of the nine plant extracts at various concentrations $(250,500,750$, and $1000 \mathrm{mg} / \mathrm{mL})$, the extracts of garlic, Solo garlic, Java plum (leaf), Kaffir lime and bitter melon showed inhibition zones in the three tested bacteria (Figure 3 ), and the bitter melon extract had the largest zone. The extracts of Java plum (fruit), Siam weed and mangosteen did not show any inhibition zones against ES $\beta$ L-producing E. coli, but demonstrated inhibition zones on MRSA and CRPA. Meanwhile, lime extract only indicated an inhibition zone on MRSA. The inhibition zones of nine extracts of the three test bacteria disclosed inhibition zone diameters of 6-19.3 mm (MRSA), 3.9-10.6 mm (ES $\beta L$ producing E. coli), and 3.9-13 mm (CRPA). $1000 \mathrm{mg} / \mathrm{mL}$ bitter melon extract indicated the largest inhibition zone diameters of the three assessed bacteria of $19.3 \mathrm{~mm}$ (MRSA), $10.6 \mathrm{~mm}$ (ES $\beta$ L-producing E. coli), and $13 \mathrm{~mm}$ (CRPA). The bitter melon extract also demonstrated a diameter of inhibition zone greater than the antibiotic control.

\section{MIC and MBC}

MIC of nine extracts was tested in vitro by the microdilution method for three resistant bacteria isolated from wounds (Table 2). The extracts of garlic, Solo garlic, Java plum (leaf), Kaffir lime and bitter melon showed MIC values between 3.12 and $25 \mathrm{mg} / \mathrm{mL}$ for MRSA, ES $\beta L$ producing E. coli, and CRPA. Among the five extracts, bitter melon presented the lowest MIC values against MRSA $(3.12 \mathrm{mg} / \mathrm{mL})$, ES $\beta L-$ producing E. coli $(12.25$ $\mathrm{mg} / \mathrm{mL})$, and CRPA $(6.25 \mathrm{mg} / \mathrm{mL})$. This result was lower than the value of antibiotic control.

MBC from nine extracts was tested in vitro by the microdilution method for three resistant bacteria isolated from wounds (Figure 4). The extracts of garlic, Solo garlic, Java plum (leaf), Kaffir lime and bitter melon showed MBC values for MRSA, ES $\beta$ L-producing E. coli, and CRPA. The extracts of Java plum (fruit), Siam weed and mangosteen did not show any MBC values for ES $\beta L$ producing $E$. coli, but demonstrated inhibition on MRSA and CRPA. However, lime extract only presented MBC values on MRSA. The MBC values ranged from 25 to 50 $\mathrm{mg} / \mathrm{mL}$.

Studies on antibacterial agents from natural ingredients are important efforts, particularly in recent times, due to the increasing level of antibiotic resistance among pathogenic bacteria. Abuse of antibiotics usage has been considered the major cause of the increasing antibiotic resistance against bacteria. The effort in this study focused on the use of widely available plants. Nine plants were used in this investigation to evaluate the antibacterial activities against MDR bacteria, including methicillin-resistant S.aureus, ESBL-producing E. coli, and CRPA, isolated from wounds. These results are consistent with the previous research reports that $S$. aureus, E. coli, and $P$. aeruginosa are the most common bacteria found in infected wounds (Manzuoerh et al. 2019; Petkovšek et al. 2009).

The nine plant extracts appeared to have inhibition zone diameters ranging from $6 \mathrm{~mm}$ to $19.3 \mathrm{~mm}$, with the most significant results were shown by the bitter melon extract. The bitter melon extract had the largest diameters of the inhibition zones in the three tested bacteria, $19.3 \mathrm{~mm}$ (methicillin-resistant $S$. aureus), $10.6 \mathrm{~mm}$ (ES $\beta$ L-producing E. coli), and $13 \mathrm{~mm}$ (CRPA), and greater diameters of inhibition zones than the antibiotic control.

The extract of bitter melon was proven to have lowest MIC and MBC values, against MRSA (3.12 and 25

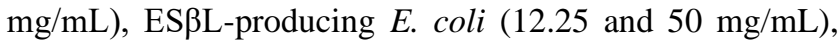
and CRPA $(6.25$ and $25 \mathrm{mg} / \mathrm{mL})$. This provides evidence that bitter melon ethanol extract shows antibacterial activities against methicillin-resistant S.aureus strains, ES $\beta$ L-producing E. coli, and CRPA. The extract displays broad-spectrum antimicrobial activities (Khan and Omoloso 1998; Mwambete 2009). Although, testing of the groups contained in bitter melon was not performed in this research, some other studies have confirmed that bitter melon contains flavonoids, alkaloids, and terpenoids (Kumar et al. 2010; Leelaprakash et al. 2011; Annapoorani and Manimegalai 2013).

Table 1. The extract yield

\begin{tabular}{|c|c|c|c|}
\hline Plants & Scientific name & $\begin{array}{c}\text { Part of } \\
\text { plants }\end{array}$ & $\begin{array}{l}\text { Yield } \\
(\%)\end{array}$ \\
\hline Garlic & Allium sativum Linn & Tuber & 1.11 \\
\hline Solo garlic & Allium sativum Linn & Tuber & 0.63 \\
\hline Java plum & Syzygium cumini (L) Skeels & Leaf & 10.30 \\
\hline Java plum & Syzygium cumini (L) Skeels & Fruit & 13.21 \\
\hline Lime & Citrus aurantifolia Swingle & Rind & 11.20 \\
\hline Kaffir lime & Citrus hystrix DC. & Rind & 14.12 \\
\hline Siam weed & $\begin{array}{l}\text { Chromolaena odorata (L) } \\
\text { RMKing \& H.Rob. }\end{array}$ & Leaf & 9.50 \\
\hline Mangosteen & Garcinia mangostana $\mathrm{L}$ & Rind & 13.10 \\
\hline Bitter melon & Momordica charantia Descourt & Fruit & 28.60 \\
\hline
\end{tabular}

Table 2. The MIC values of nine plant extracts against MRSA, ESBL-producing E. coli and CRPA (mg/mL)

\begin{tabular}{lccc}
\hline \multirow{2}{*}{ Extract and control } & \multicolumn{3}{c}{ Tested bacteria } \\
\cline { 2 - 4 } & MRSA & ESBL-E.coli & CRPA \\
\hline Garlic & 12.5 & 25 & 12.5 \\
Solo garlic & 25 & 25 & 12.5 \\
Java plum (leaf) & 25 & 25 & 12.5 \\
Java plum (fruit) & 25 & - & 25 \\
Lime & 25 & - & - \\
Kaffir lime & 12.5 & 25 & 12.5 \\
Siam weed & 25 & - & 25 \\
Mangosteen & 12.5 & - & 25 \\
Bitter melon & 3.12 & 12.5 & 6.25 \\
Oxacillin & 4 & - & - \\
Ampicillin & - & 32 & - \\
Meropenem & - & - & 16 \\
\hline
\end{tabular}


The antibacterial activities of plants can be related to phytochemical compounds which can protect the human body against microbial infection. The most important phytochemicals are flavonoids, alkaloids, and terpenoids (Kumar et al. 2013). Flavonoids (Khalid et al. 2019) and terpenoids (Broniatowski and Mastalerz 2015) have been recognized to show strong antibacterial activities. The mechanism of antibacterial activities of flavonoids, alkaloids, and terpenoids in bitter melon has not been identified. However, phytochemical compounds can inhibit bacterial growth by damaging bacterial cell walls (Abuga et al. 2020). Bitter melon is proven to be potentially developed as an antibacterial agent, especially for MDR strains from wounds. Further in vivo research and the investigation of modes of action are essential to explicate the antibacterial effects so that potential clinical drugs and health products can be advanced. This study can provide novel information about the benefits of bitter melon as a natural source of the antibacterial agent against MDR bacteria.

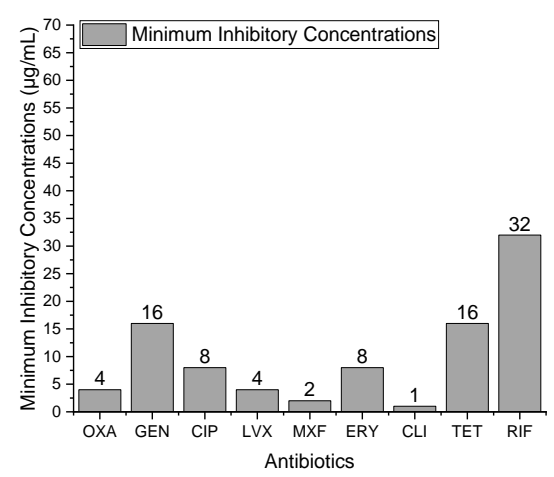

S. aureus
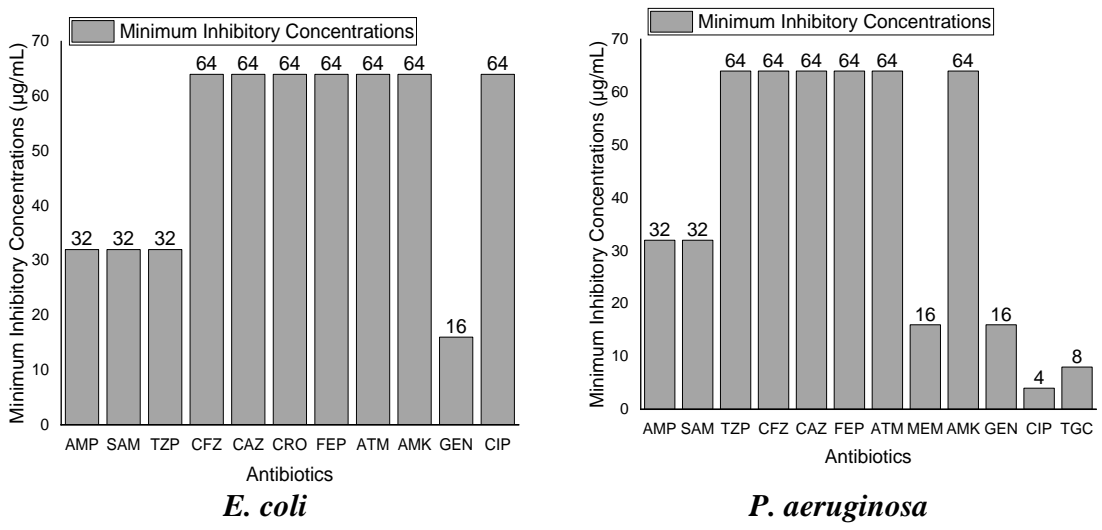

Figure 1. The results of identification and sensitivity to bacterial antibiotics isolated from wounds. OXA: Oxacillin; GEN: Gentamicin; CIP: Ciprofloxacin; LVX: Levofloxacin; MXF: Moxifloxacin; ERY: Erythromycin; CLI: Clindamycin; TET: Tetracyclin; RIF: Rifampicin; AMP: Ampicillin; SAM: Ampicillin-sulbactam; TZP: Piperacillin-tazobactam; CFZ: Cefazolin; CAZ: Ceftazidime; CRO: Ceftriaxone; FEP: Cefepime; ATM: Aztreonam; AMK: Amikacin; MEM: Meropenem; TGC: Tigecycline

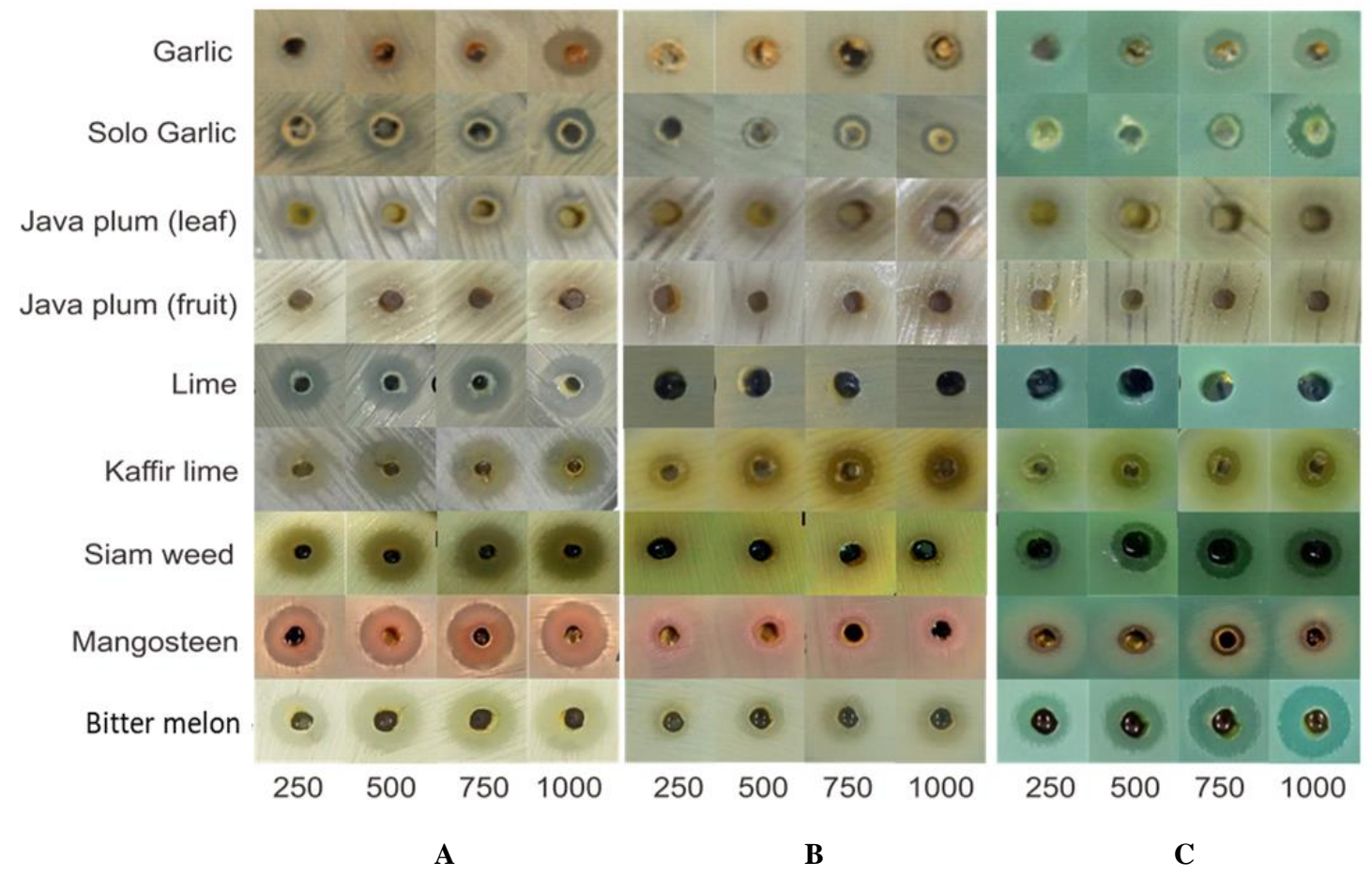

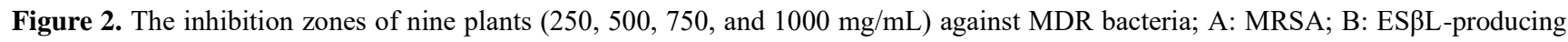
E. coli; C: CRPA 

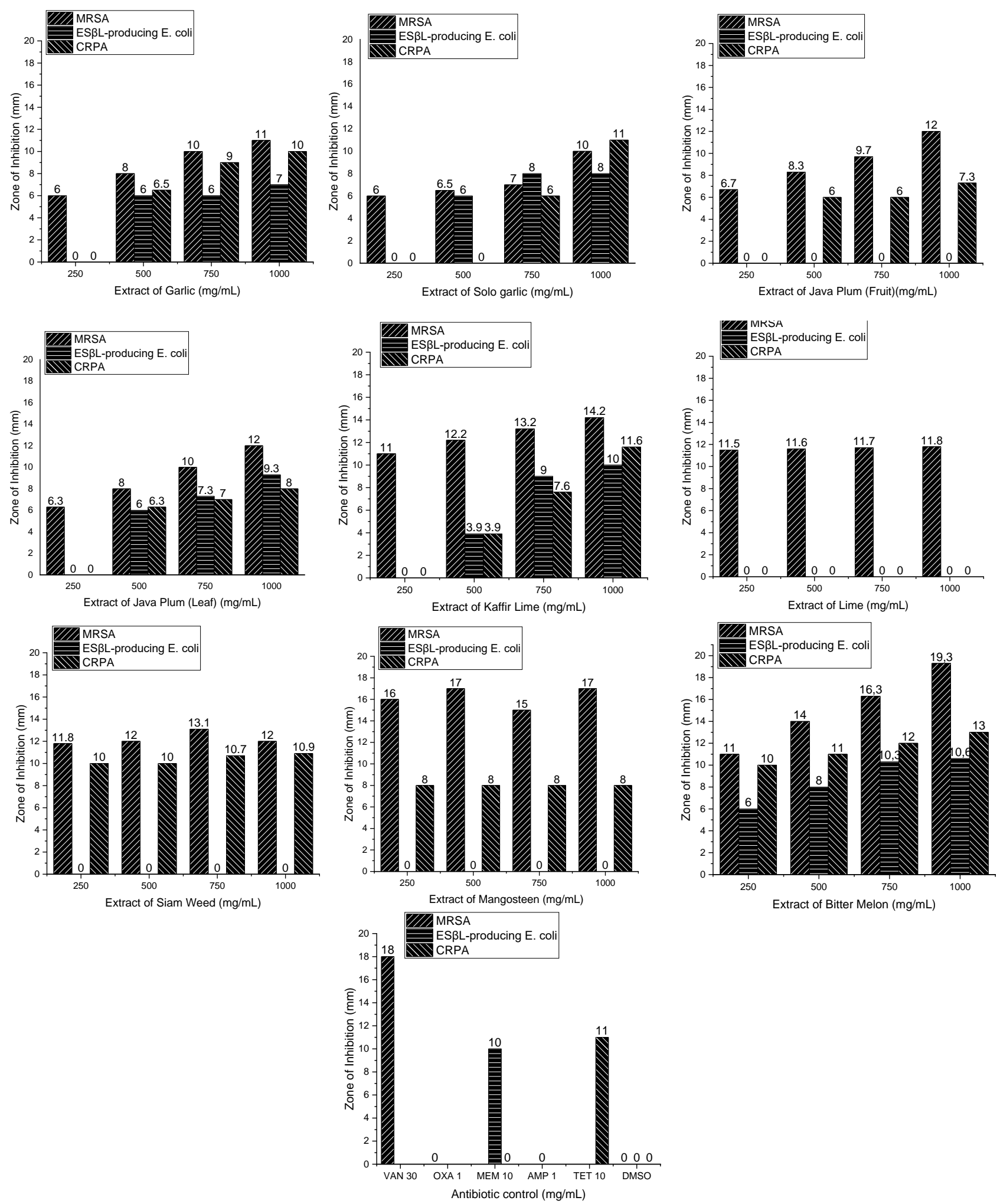

Figure 3. The diameters of the inhibition zones of nine plants. Vancomycin (VAN) and oxacillin (OXA) were used as positive controls for MRSA, ampicillin (AMP) and meropenem (MEM) for ESBL-producing E. coli, and meropenem (MEM) and tetracycline (TET) for CRPA. 


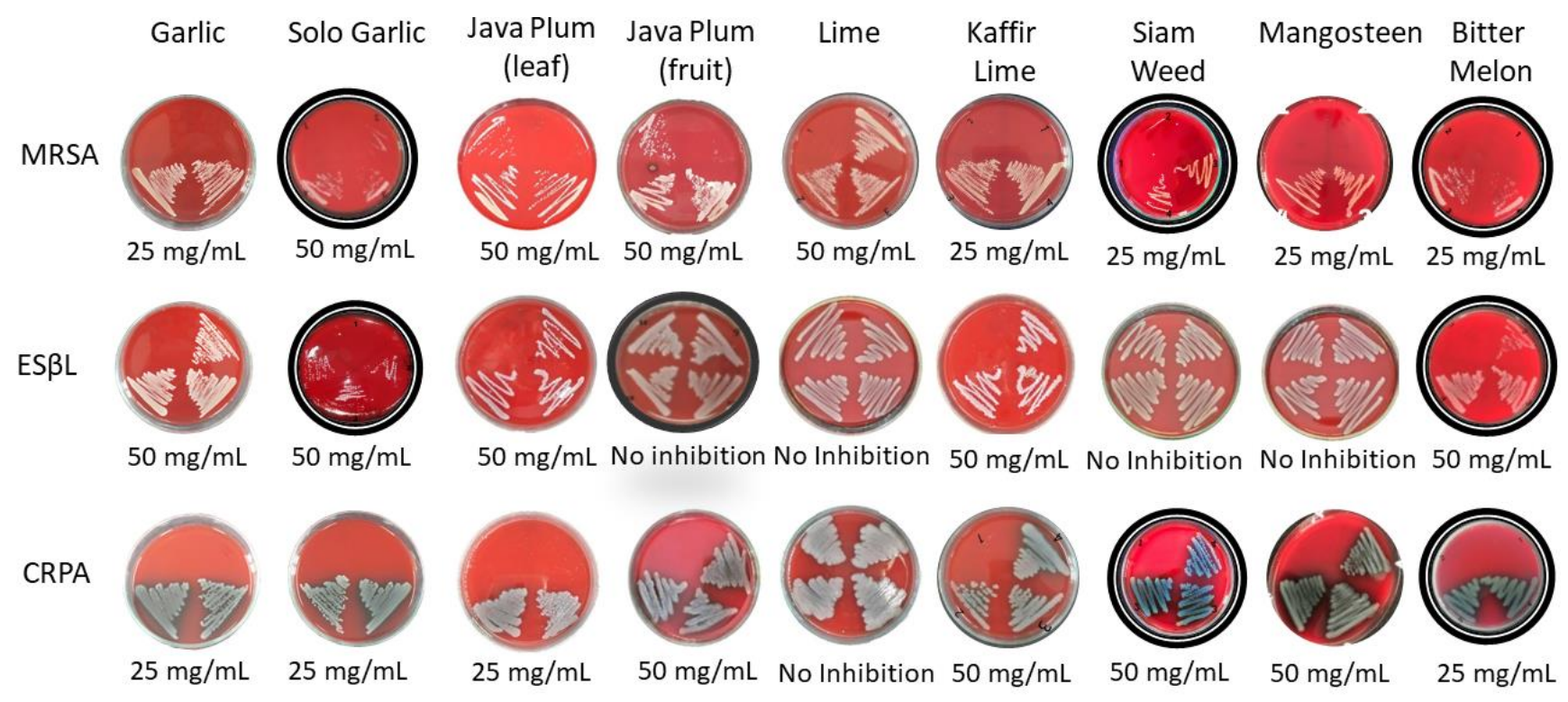

Figure 4. The MBC values of nine plant extract against MRSA, ESBL-producing E. coli and CRPA

In conclusion, the bitter melon has the potential to be developed as an antibacterial agent, particularly against methicillin-resistant $S$. aureus strains, ES $\beta$ L-producing $E$. coli, and CRPA that cause wound infections. Further, in vivo research and the discovery of modes of action are needed to explain the antibacterial effects.

\section{ACKNOWLEDGEMENTS}

The author would like to acknowledge Department of Medical Laboratory Technology, Universitas Muhammadiyah Semarang, Indonesia, for providing essential facilities for carrying out the study.

\section{REFERENCES}

Abuga I, Fariza S, Abdul R, Leong K, Syaiful M, Abdull B. 2020. In vitro antibacterial effect of the leaf extract of Murraya koenigii on cell membrane destruction against pathogenic bacteria and phenolic compounds identification. Eur J Integr Med 33: 101010. DOI: 10.1016/j.eujim.2019.101010.

Akhtar N, Mirza B. 2015. Phytochemical analysis and comprehensive evaluation of antimicrobial and antioxidant properties of 61 medicinal plant species. Arabian J Chem 11 (8): 1223-1235. DOI: 10.1016/j.arabjc.2015.01.013.

Andleeb S, Alsalme A, Al-zaqri N, Warad I, Alkahtani J. 2020. In-vitro antibacterial and antifungal properties of the organic solvent extract of Argemone mexicana L. J King Saud Univ Sci 32 (3): 2053-2058. DOI: 10.1016/j.jksus.2020.01.044.

Annapoorani CA, Manimegalai K. 2013. Screening of medical planta Momordica carantia for secondary metabolites. Intl J Pharm Res Dev 5: $1-6$.

Asagabaldan MA, Bedoux G, Bourgougnon N. 2019. Bacterial isolates from bryozoan Pleurocodonellina sp.: Diversity and antimicrobial potential against pathogenic bacteria. Biodiversitas 20: 2528-2535. DOI: $10.13057 /$ biodiv/d200914.

Aumeeruddy-elalfi Z, Gurib-fakim A, Mahomoodally F. 2015. Antimicrobial, antibiotic potentiating activity and phytochemical profile of essential oils from exotic and endemic medicinal plants of Mauritius. Ind Crop Prod 71: 197-204. DOI: 10.1016/j.indcrop.2015.03.058.

Bologa CG, Ursu O, Oprea T, Melançon CE, Tegos G. 2013. Emerging trends in the discovery of natural product antibacterials. Curr Opin Pharmacol 13: 678-687. DOI: 10.1016/j.coph.2013.07.002.

Boucher HW, Talbot GH, Bradley JS, Edwards JE, Gilbert D, Rice LB, Scheld M, Spellberg B, Bartlett J. 2009. Bad Bugs, No Drugs: No ESKAPE! An Update from the Infectious Diseases Society of America. Clin Infect Dis 48: 1-12. DOI: $10.1086 / 595011$.

Broniatowski M, Mastalerz P. 2015. Biochimica et Biophysica Acta Studies of the interactions of ursane-type bioactive terpenes with the model of Escherichia coli inner membrane - Langmuir monolayer approach. Biochimica et Biophysica Acta (BBA)-Biomembranes, 1848 (2): 469-476. DOI: 10.1016/j.bbamem.2014.10.024.

Chopra S, Harjai K, Chhibber S. 2016. Potential of combination therapy of endolysin MR-10 and minocycline in treating MRSA induced systemic and localized burn wound infections in mice. Intl $\mathrm{J}$ Med Microbiol 306: 707-716. DOI: 10.1016/j.ijmm.2016.08.003.

CLSI. 2019. M100 Performance Standards for Antimicrobial Susceptibility Testing, 29th eds, Journal of Services Marketing. Clinical and Laboratory Standards Institute, Wayne, PA, USA. DOI: 10.1108/08876049410065598.

CLSI. 2018. M07: Methods for Dilution Antimicrobial Susceptibility Tests for Bacteria That Grow Aerobically, 11th ed. Clinical and Laboratory Standards Institute, Wayne, PA, USA.

Han G, Ceilleey R. 2017. Chronic Wound Healing: A review of current management and treatments. Adv Ther 34: 599-610. DOI: 10.1007/s12325-017-0478-y.

Ilvani E, Wilson W, Prastiyanto ME. 2019. Uji antibakteri ekstrak etanol biji pepaya (Carica papaya L .) terhadap pertumbuhan Escherichia coli ESBL. Prosiding Seminar Nasional Mahasiswa Unimus 2: 24-31.

Khalid M, Bilal M, Dan-feng H. 2019. ScienceDirect Role of flavonoids in plant interactions with the environment and against human pathogens-A review. J Integr Agric 18: 211-230. DOI: 10.1016/S2095-3119(19)62555-4.

Khan M, Omoloso A. 1998. Momordica charantia and Allium Sativum: Broad-spectrum antibacterial activity. Korean J Pharmacogn 29: 15558. DOI: $10.4236 / \mathrm{cm} .2011 .24021$.

Kumar DS, Sharathnath KV, Yogeswaran P, Harani A, Sudhakar K, Sudha P, Banji D. 2010. a medicinal potency of Momordica charantia. Intl J Pharmaceut Sci Rev Res 1: 95-100.

Kumar SR, Loveleena D, Godwin S. 2013. Medicinal property of Murraya koenigii - a review. Intl Res J Biol Sci 2: 80-83. 
Leelaprakash G, Rose JC, Javvaji. 2011. Invitro antimicrobial and antioxidant activity of Momordica charantia. Pharmacophore 2: 244252.

Lestari SD, Sadiq ALO, Safitri WA, Dewi SS, Prastiyanto ME. 2019. The antibacterial activities of bacteriocin Pediococcus acidilactici of breast milk isolate to against methicillin-resistant Staphylococcus aureus. J Phys Conf Ser 1375: 012021. DOI: 10.1088/17426596/1374/1/012021.

Liang Y, Zhao X, Hu T, Han Y, Guo B. 2019. composite hydrogel wound dressing to promote the regeneration of infected skin. J Colloid Interface Sci 556: 514-528. DOI: 10.1016/j.jcis.2019.08.083.

Manzuoerh R, Reza M, Oryan A, Sonboli A. 2019. Biomedicine \& pharmacotherapy original article effectiveness of topical administration of Anethum graveolens essential oil on MRSAinfected wounds. Biomed Pharmacother J 109: 1650-1658. DOI 10.1016/j.biopha.2018.10.117.

Mwambete KD. 2009. The in vitro antimicrobial activity of fruit and leaf crude extracts of Momordica charantia: A Tanzania medicinal plant. Afr Health Sci 9 (1): 34-39.

Nasser M, Ogaili M, Palwe S, Kharat AS. 2020. Molecular detection of extended spectrum $\beta$-lactamases, metallo $\beta$-lactamases, and Amp-C $\beta$ lactamase genes expressed by multiple drug-resistant Pseudomonas aeruginosa isolates collected from patients with burn/wound infections. Burn Open 4: 160-166. DOI: 10.1016/j.burnso.2020.07.003.

Pallavali RR, Avula S, Lakshmi V, Penubala M, Damu AG, Raghava V, Durbaka P. 2019. Data of antibacterial activity of plant leaves crude extract on bacterial isolates of wound infections. Data in Brief 24: 103896. DOI: 10.1016/j.dib.2019.103896.

Panjaitan RA, Darmawati S, Prastiyanto ME. 2018. Aktivitas antibakteri madu terhadap bakteri multi drug resistant Salmonella typhi dan Methicillin-Resistant Staphylococcus aureus. Prosiding Seminar Nasional \& Internasional 1 (1). [Indonesian]

Petkovsek Z, Elersic K, Gubina M, Zgur-Bertok D, Erjavec S. 2009. Virulence potential of Escherichia coli isolates from skin and soft tissue infections` iva Petkovs. J Clin Microbiol 47: 1811-1817. DOI: 10.1128/JCM.01421-08.

Prastiyanto ME, Azizah IH, Haqi HD, Yulianto BD, Agmala AB, Radipasari ZD, Astuti NA, Putri AR. 2020a. In-vitro antibacterial activity of the seed extract of three members Artocarpus towards methicillin-resistant Staphylococcus aureus (MRSA). J Teknol Lab 9: 1-6. DOI: 10.29238/teknolabjournal.v9i2.237.

Prastiyanto ME, Rukmana RM, Saraswati DK, Darmawati S, Maharani ETW, Tursinawati Y. 2020b. Anticancer potential of methanolic extracts from Pleurotus species on raji cells and antibacterial activity against Methicillin-Resistant Staphylococcus aureus. Biodiversitas 21: 5644-5649. DOI: 10.13057/biodiv/d211221.

Prastiyanto ME, Setyaningtyas A, Trisnawati L, Syafira A. 2016 Antimicrobial activity and identification the compounds of methanol extract from the Pleurotus ostreatus fruiting body. el-Hayah J Biologi 6: 29-34. DOI: 10.18860/elha.v6i1.4082. [Indonesian]

Prastiyanto ME, Tama PD, Ananda N, Wilson W, Mukaromah AH. 2020c. Antibacterial potential of Jatropha sp. Latex against Multidrug-Resistant Bacteria. Intl J Microbiol 2020. DOI: 10.1155/2020/8509650.

Prastiyanto ME, Wardoyo FA, Wilson W, Darmawati S. 2020d. Antibacterial activity of various extracts of Averrhoa bilimbi against Multidrug-Resistant Bacteria. Biosaintifika 12: 163-168. DOI: 10.15294/biosaintifika.v12i2.23600

Prastiyanto ME, Rohmah N, Efendi L, Arifin R, Wardoyo FA, Wilson W, Mukaromah AH, Dewi SS, Darmawati S. 2021. Antifungal activities of the rhizome extract of five members Zingiberaceae against Candida albicans and Trichophyton rubrum. Biodiversitas 22: 15091513. DOI: 10.13057/biodiv/d220355.

Wahyuni RA, Putri IY, Jayadi EL, Prastiyanto ME. 2019. Aktivitas antibakteri ekstrak buah parijoto (Medinilla speciosa) terhadap bakteri Extended Spectrum Betalactamase (ESBL) Escherichia coli dan Methicillin Resistant Staphylococcus aureus (MRSA). J Media Anal Kesehatan 10: 106-118. DOI: 10.32382/mak.v10i2.1250.

Xu R, Luo G, Xia H, He W, Zhao J, Liu B, Tan J, Zhou J, Liu D, Wang Y, Yao Z, Zhan R, Yang S, Wu J. 2015. Biomaterials Novel bilayer wound dressing composed of silicone rubber with particular micropores enhanced wound re-epithelialization and contraction. Biomaterials 40: 1-11. DOI: 10.1016/j.biomaterials.2014.10.077.

Yin C, Xie L, Guo Y. 2018. Phytochemical analysis and antibacterial activity of Gentiana macrophylla extract against bacteria isolated from burn wound infections. Microb Pathog 114: 25-28. DOI: 10.1016/j.micpath.2017.10.049 